\title{
Hate Speech and Caucasian Nationalism in Western Democracies: Flashing Light on the Invisible Ghost
}

\author{
Emmanuel K. Ngwainmbi
}

\begin{abstract}
This article describes the sociology of hate speech, contending that hate speech is a by-product of racism that dominates our world when homo sapiens occupy the universe. It analyzes ideas of national space by some race thinkers and points to contemporary media as the foremost promoter of Caucasian nationalism worldwide. The article shows how social media data and IT platforms advance anti-other sentiments and a particular egocentric pro-nationalist agenda among Caucasian groups in the Global North, especially Germany and America. Convinced by Sigmund Freud's argument that human behavior is motivated by unconscious conflicts almost always aggressive. The principles of reverse psychology and group communication explain how the media frames persons with different racial, ethnic, sexual, gender, or ethnic configurations. Presenting hate speech as a threat to world peace and demonstrating that counter speech is a better way of blocking hate speech's dignitarian harm [1], the paper identifies global efforts to curb hate speech and shows how media firms and governments can control hate speech.
\end{abstract}

Keywords - Caucasian nationalism, hate speech, Hitler, media, neo-Nazi, western democracies.

\section{INTRODUCTION}

Hate speech is any verbal or nonverbal communication or behavior that uses pejorative or discriminatory language on persons or groups based on religion, ethnicity, color, descent, sexual orientation, creed, or nationality. The locus is that persons within the dominant group use their in-group status (power, privileges, and social class) to ostracize disadvantaged ethnic group member(s) - primarily Blacks (Africans; Afro-Caribbeans, Afro-Asians), Asians, and members of the LGBT) lesbian, gay, bisexual, and transgender) community. To wit, recent media coverage of Caucasian nationalists claiming complete control over minority groups as well as rich and developing countries' economies and governing methods have escalated in Western countries over the last few decades. Caucasian groups in Europe and America have been invading the streets and online platforms with information that denigrates minority and vulnerable populations, re-igniting fears of a neo-Nazi takeover of democratic communities and reversing civil rights benefits. In response to this onslaught, United Nations Secretary-General Antonio Gutierrez has encouraged the world governing body to intensify its work on hate speech to prevent armed conflict, crime, and terrorism, end violence against women and other severe violations of human rights, and promote peaceful, inclusive and just societies [2]. Each member state is, thus, responsible for the outcome, depending on the cost of exercising free expression within its territory; it has the right to monitor the influence and dangers of hate speech shared by internal and external bodies that affect the lives of its citizens. To ensure all inhabitants exercise that fundamental right, some nations have rules that check the delivery and management of free expression. To measure the value of the rules, we need a context--a theoretical framework of nationalism.

\section{THEORETICAL FRAMEWORKS}

The arguments in this article are guided by existing notions of nationalism, mainly that the nation is an imagined community, a space with defined boundaries, a history, heritage, way of life that can be unique or complex. The nation could be a fabrication, a bond between people that did not exist before its recognition [3], or any sufficiently large body of people whose members regard themselves as members of a nation. But people living within that 'fabricated' space may see themselves as something else, not members of the nation. Previous constructivist views of nationalism are that pre-existing and homogenous characteristics of a people group do not define a nation; instead, these constructivists think it is a bond [4].

To clarify, I point to a study of the Thai people by Thong chai Winichakul several decades ago where cultural nationalists, ex-leftists, made a distinction between a 'bad' nationalism and embraced the 'good' one, rejecting the former. Winichakul [5] noted that such sentiments of nationalism, widespread among the Thai intelligentsia, were essential in supporting the military coup in Thailand. Given that scenario, we might conclude that one's perceptions of belonging to the nation depend on primitive concepts of the self, be they religious, conservative, rural, or urban.

To clarify that position, I shall discuss different perceptions and manifestations of hate speech in agrarian and cosmopolitan milieus, beginning with factors that promote the dissemination of hate speech.

\section{CONCEPTUAL FramewORKS}

\section{A. Hate Speech Enablers}

In my edited book, Dismantling Cultural Borders through 
Social Media and Digital Communications, published by Palgrave in 2022 [6], my readers note that we have raised a red flag against some prominent Western broadcast media agencies for spreading harmful speech and cultural xenophobia worldwide. We have opined that televised hate groups thought to be expressing their rights as humans have escalated over the past twenty years, prompting other groups and institutions to question the media's true identity. Why? This is partly because Western media broadcast images of Zionist groups on streets in Europe and showcase the Black Lives Matter and Proud Boys movements in America and White police beating against Blacks. Established media outlets like the Associated Press, BBC, and Agence France Presse prioritized that story over more important stories like the Coronavirus and American presidential politics. Similar hate-based activities begin online and eventually influence political activists and hate-mongers, generating angst on the public's global conscience. My position is predicated on the stance that the most influential news networks around the world habitually pull stories from the Associated Press, the 215-years old unbiased news bank renown for selling to an estimated 15,000 news organizations worldwide.

\section{B. The psyche of the Racist}

The mind of a racist is a complex combination of fear of the unknown and a strong desire to protect selfish values. Cognitive neuroscience informs us that people who display implicit bias against others have a more robust electrical response to other-race faces in the amygdala - a brain responsible for processing emotional stimuli and eliciting a fearful or anxious mental state [7]. Bias is an automatic response involving a complex neurological interplay between "prejudice" and "stereotype," the former described as an adverse emotional reaction to out-group members and the latter, a set of cognitive beliefs about those members. For Amodio and Devine [8], bias is acquired by connecting distinct neural substrates associated with necessary affective and semantic behaviors. Semantic behaviors include careful words and gestures to undermine out-group members in conversations and other informal contexts. For example, humor, ridicule, and joke-telling are part of bigotry, often masquerading as "jokes."

However, we should not replace the notion of 'racist' or 'white nationalist' with majority members of society who knowingly or absent-mindedly take their cultural norms for granted and speak carelessly to others. The actions of such members have nothing directly to do with race, which is experienced on various levels everywhere in human society relative to multiple categories of identity. Problems that culminate in the use of hate speech cull from anger, resentment, and ignorance.

Canadian psychologists show how dominant group motives are expressed through cavalier beliefs about humor. Hudson and McInnis report that humor and ridicule operate in tandem with dehumanization and play a critical part in the de-legitimization process [9]. But hateful expressions cannot be determined only by one's race but by one's environment. A child who grows up in a home where derogatory adjectives, adverbs, and verbs are used when describing persons from another race is likely to despise the latter in its adult life blatantly. Indeed, the psychology of unconscious bias holds that hate groups practice implicit racial discrimination, knowingly and inadvertently affecting how they perceive others, process information about others, and interact with their social world. Racial groups with those qualities have a collective consciousness transmitted from generation to generation, and they maintain cohesiveness and hate practices over time.

\section{E-communication Channels as Hate-speech Engine}

Electronic communication systems are the best conduits of hate speech as they instantly transmit all types of content created anywhere. For Western media, the range of cultural events is policed by mediated language use. In America, for example, Spanish-speaking people consume content from three major satellite broadcast networks - Telemundo, Unimás, and Univision. At the same time, a relatively small English-speaking audience follows the Qatar governmentowned Aljazeera or CTGN, the China Global Television Network that brings a Chinese perspective to global news. The point suggested here is that people are jealously attached to news flows that reflect or validate what they know or need to know about their culture.

That is partly why hate speech narratives are brewing online so much that, I believe, the media with a global reach has influenced discord among ethnic and racial groups. News reporters select words and images to persuade media audiences to think differently about their opinions on hateful behaviors. For example, after a Wisconsin police officer had killed George Floyd, a black man, alleging he used a counterfeit currency in a grocery store, CNN, Fox News, and other television network news anchors spent numerous hours covering the story; they interviewed angry demonstrators, lawmakers, administrators, and pro-minority activists, fueling hate messaging against the establishment. Demonstrations across American cities ensued, forcing companies and the US Congress--the judicial branch of the government--to take measures to change public discourse about black people. During street demonstrations, protesters from different socio-ethnic backgrounds with face masks and placards wanted the police departments defunct.

The news media and talk show hosts covered speeches by prominent lawmakers, celebrities, religious figures, educators, professional athletes, and media experts, further sensitizing the public about the already widely mediatized event. Hate narratives prevailed on other media platforms.

In an article posted online, August 9, 2019, New York University's School of Public Health reported that the number of hate crimes in major U.S. cities had risen for the third consecutive year in 2017, primarily driven by attacks on Jews, Muslims, Blacks, and LGBT people. Alongside this increase, online hate speech, one type is race, ethnicity, and ancestry-based discrimination was visible on platforms such as WhatsApp, Twitter, and Facebook. Such speech elevated violence and crime to a new level.

Also, during the United Nations General Assembly's 70th Session held in September 2015, broadcast worldwide, the world governing body called its 193 member countries to act urgently to end violence and discrimination against lesbian, gay, bisexual, transgender, intersex (LGBTI) persons, adults, adolescents, and children [10]. Asserting that all people have equal rights to lead a life free from violence, persecution, 
discrimination, and stigma, the world governing body has established an international human rights law providing legal obligations on member nations to ensure that every person, without distinction, can enjoy these rights [11]. Yet, among the nations that advocate free expression like the United States, legislators appear to be lukewarm in implementing individual rights for everyone.

Undoubtedly, freedom is a chaotic phenomenon. The Proud Boys, a neo-fascist, exclusively male chauvinist organization that claims to defend Caucasian male culture but uses violence as a form of initiation into their ranks, engages in political violence in the United States and Canada. The group has enjoyed ample, free local and international press coverage, raising questions about how news consumers see Caucasians in their respective communities.

\section{Ethnic groups movements and hate speech euphoria}

The euphoria over the "Black Lives Matter" movement spotlighted harmful expressions against blacks. However, it is hard to place that movement within the same neo-cultural space as the Proud Boys movement, as coverage of the two political groups is grossly imbalanced. The former group has received more coverage, but more community groups support the Proud Boys' platform. Given that 74 million Americans (representing 46.8\%) voted for Donald Trump, a candidate who publicly supported the Proud Boys' movement (the neofascist, male organization promoting and engaging in political violence in the United States) throughout the 2020 US Presidential election, I must insist that the Proud Boys' agenda has ineligible traction. Although their content has been banned from social networks, including Facebook, Instagram, YouTube, and Twitter [12], and some of its members have been indicted by the United States Justice Department for their actions during the infamous attack on the United States building on January 6 2021, more Caucasians privately support the group's fight to sustain Western culture - a way of life supposedly supreme to any other tradition worldwide.

In a similar instance, BBC News, in May 2019, highlighted public support for right-wing nationalist parties across 17 European countries after a far-right Hungary-based nationalist party and a member of the ruling alliance government won more than 49 percent of the votes during the 2018 national elections. The media provided profuse coverage when the nationalist party won more than 25 percent [13]. Meanwhile, BBC reports focused on violence in Asia instigated by religious extremists. In Sri Lanka and Myanmar, nationalist Buddhist monks made fiery speeches, inciting violence against minority groups.

On May 25, 2020, when a police officer in Minneapolis, Minnesota, USA, murdered the 46-years old George Floyd, the media reported anti-police sentiments and demonstrations across the American cities and worldwide. Some communication channels disseminated racy statements posted on a Facebook page, The Truth Show, published June 24,2020 . WhatsApp, for example, is shared with millions of people. The posting carried the following sarcastic expressions, reflecting the news media's dubious modus operandi:

- when a white person kills a black person, that's called

\section{'self-defense.'}

- when a black person kills a black person, that's called 'gang violence.'

- $\quad$ when a Muslim kills anyone, it is called 'terrorism.'

- when a white person kills another white person, it is called a 'mental health crisis.'

- when a black person kills a white person, it is called 'murder.'

- when a white person kills a black person, that is called 'self-defense.' [14].

Based on those knowledge-sharing patterns, we may say that targeted communication tools serve as enablers of hate speech by specific ethnic groups.

\section{E. Watching the Ghost: Social media, the African- American experience, and sociological discourse}

The profuse use of mobile phones, text messaging, e-mail and chat rooms have fostered aggressive social interaction and victimization of young people, senior citizens, LGBTs, and other vulnerable groups. Rowell Hussmann regrets the current trend by stating that new venues break old boundaries of family, neighborhood, and community that have protected our youth to some extent in the past [15]. Nothing starkly explains the impact of hate speech on a minority group than the story of a white minister, Charles Moore, who set himself on fire in 2014 to protest racist acts in his town, Grand Saline, Texas.

To better understand the levels of resistance to hate speech and how social media serves as the invisible advocate of hate speech, we need to know the mindset of a victim--the African American. Afrocentric scholar Molefi Kete Asante provides an intercontinental framework for understanding hate narratives against minority groups and suggests countering negative thoughts about blacks based on race, skin color, and socio-ethnic composition, including the removal of Europe from the center of the African reality [16]. Afrocentricity is a revolutionary idea because it considers ideas, concepts, events, personalities, and political and economic processes from the standpoint of black people. The latter are subjects and not objects, and all knowledge is based on the authentic interrogation of location [17].

Conversely, Christian principles, not ideologies of Afrocentricity, deeply rooted in the American society since the Puritan era through the 21st century, shape AfricanAmericans' identity. Christianity is thus introduced to demean and undermine Blacks. Following its introduction in 1701 to Black slaves, the majority in this group (politically described as African-Americans) continues to rely heavily on the Christian church for psycho-social and economic inspiration and direction. Today, that majority confront any amount of hate speech targeting them on home turf (country) or abroad, primarily from a Judeo-Christian viewpoint.

\section{LITERATURE REVIEW}

\section{G. Hate Speech and Western Nationalism}

Nationalism is a component of culture if we see culture as things a social group or nation celebrates--customs, arts, social institutions, and achievements. Thus, nationalism is an expression from which others can deduce positive and harmful practices. The nationalist ideology does not exclude 
eccentricity or selfishness; it includes 'ownership' of defined boundaries and dominant values enacted within those boundaries. Nationalists accept an idea shared in any tone or language that supports a sense of belonging to that space.

On a national level, just as a society structured along racial lines produces offensive, racist arguments hate speech can bring violence, massive killing, and marginalization of the group or race, especially when our expressions are protected by state laws and language is used with no consideration recourse for unity in any pluralistic society. Two nations in recent memory depict the relationship between hate speech and violence - Germany and the United States of America.

\section{F. The rise of Nationalist Sentiment in Germany}

Radical-nationalist groups and political campaigns are common in Germany as protesters publicly express their sentiments against the German government's immigration policies, clearly accusing German Chancellor Angela Merkel's Christian Democratic Union party of threatening to deprive them of their ancestral territory.

Consider this case. When Austrian-born German politician Adolph Hitler, while commenting about globalization, says, "this large international power (Jews) organizes its terror groups by appealing to their lower instincts but also reduces their potential resistance through intellectual influence," Hitler has unleashed verbal venom to poison the minds of fellow Germans and pro-Jewish people, setting the stage for build-ups to a genocidal process against the arch-villains of internationalism: Jews. Hitler's ultimate plan to exterminate Jews developed incrementally after this speech was broadcast on German radio airwaves. Rabbi Shaina Bacharach, in a blog published on Kant Media, August 28, 2019, a German-based publication, describes Hitler's persuasive narrative that includes "the building blocks of the Nazis, national expansion and acquisition of land; the need for space; jobs for "real" Germans; no immigration; no globalism, and most of all, the danger posed by the Jews [18]. To me, that pro-nationalist declaration is the deadliest form of hate speech because its rhetoric involves selfish national interest and hatred for Jewish sentiments. Hitler continues his racist rants against Jews, scolding news reports he believes accuse him of military aggression, even though he is amidst a military onslaught staged by the coalition. He unapologetically describes the world's sympathy for Jews in this rhetoric:

The world has sufficient space for settlements, but we must once and for all get rid of the opinion that God only created the Jewish race to be in a certain percentage a parasite living on the body and the productive work of other people nations. The Jewish race will have to adapt itself to sound constructive activity as other nations do, or sooner or later, it will succumb to a crisis of an inconceivable magnitude [19].

Hitler issues those brilliant statements to convince the rest of the world to accept his planned genocide against the Jewish people. He further incites anti-Jewish sentiments across the German territory in his subsequent argument:

During the time of my power struggle, it was in the first instance the Jewish race which only received my prophecies with laughter when I said that I would one day take over the leadership of the State, and with it that of the whole nation, and that I would then among many other things settle the Jewish problem. Their laughter was uproarious, but I think they have been laughing on the other side of their face for some time now. Today I will once more be a prophet: If the international Jewish financiers in and outside Europe should succeed in plunging the nations once more into a world war, then the result will not be the Bolshevization of the earth, and thus the victory of Jewry, but the annihilation of the Jewish race in Europe! The nations are no longer willing to die on the battlefield so that this unstable international race may profiteer from a war or satisfy its Old Testament vengeance. The Jewish watchword "Workers of the world unite" will be conquered by a higher realization, namely, "Workers of all classes and all nations, recognize your common enemy!" [20].

That vitriol, widely disseminated among Hitler's army and the population in neighboring countries via German radio and newspapers, convinces Germans it is necessary to exterminate the powerless (Jews). His radio broadcasts and rebroadcasts produce enough propaganda, culminating in a holocaust, asserting dehumanizing rhetoric precedes violence.

\section{G. Hate Speech, Neo-Nazis, and the Rise of Nationalism}

The same propaganda prevailed between 2010 and 2020 as neo-Nazis claimed the need for territorial protection and fostered the perception that immigrants might take over their territory and deprive them of homeland resources. During the political crises in the Middle East, Syrian refugees flocked into Germany as the Nazis quickly posted anti-Syrian placards online and in the streets advocating their repatriation. As German newspapers like BILD, with an average daily print circulation of three million copies (2020 estimates) and the Frankfurter Allemeine (300,000 circulation size) covered clashes between Germans and Syrian refugees in the suburban areas, other reports accused German media of biased coverage framed to deepen the rift between liberals, nationalists, and conservatives. Research shows that since 2015, families and focus groups have been privately discussing neo-Nazi rhetoric and the Syrian refugee crisis following the arrival of over one million immigrants.

From 2016 and 2019, more than 500,000 men and women marched through streets in Munich and other major cities carrying the German flag and placards with messages such as "Wacht Auf! Die Hand, die einen füttert, beißt man nicht. Wir sind das Volk!" ("Wake up! Do not bite the hand that feeds you! We are the people!"). It should be noted that "We are the people!" was used by citizens of the German Democratic Republic (East Germany) during the political change in 1989. Other banners had the following messages:

"Rettet das Volk vor den Buntfaschisten"

(Save the people from the colorful fascists). "Colorful fascists" is a derogatory expression about the Green Party. Per this author's discussions with Germans, "colorful fascists" means that the Green Party wants to see all Germans extinct.

Other placards had these messages: 


\section{"Danke dem PEGIDA Team. Viel Erfolg"}

("Thanks to the pegida team. Much success." Pegida is the acronym for Patriotische Europäer Gegen die Islamisierung des Abendlandes-Patriotic Europeans Against the Islamization of the Occident, including Germany. It is a pro-National, Pan-European, anti-Islam, far-right political movement founded in Dresden, Germany, October 2014.

By carrying banners depicting Europe (the Occident) or Germany as a traditional Judeo-Christian nation increasingly Islamized, not only have the German Pegida supporters defined themselves as a group opposing Islamic extremism. They unleash Islamophobia, the most potent form of hate speech against Muslims - reminiscent of Hitler's rhetoric that spread anti-Semitic feelings across Germany, prompting nationalists in that country to develop sentiments Shoah-like sentiments, Holocaust.

Even the demonstrators' widely mediatized claim that the Green party--a German-based political party-wants to eliminate Germans from their ancestral space--can incite outrage across Germany. Moreover, the Green Party's mantra is Marxism, pacifism, ecologism, and social change. The Greens exist because they fit perfectly into a society where unconventionality has become the norm, explaining the reemergence and retaliation of the Neo-Nazis movement in Germany.

In the past few decades, Nazis have been using propaganda against immigrants, leading to a rise in the use of Nazi phrases amid unpreceded growth in attacks on asylum seekers. Thousands of Nazis have thronged the streets hoisting posters with anti-immigrant invectives. In 2016, Interior Minister, Thomas de Maiziere, released national crime statistics, which showed that in 2014 and 2015 alone, attacks on persons seeking asylum influenced by publicly-staged hate language increased more than five times. Crimes targeting asylumseekers homes quadrupled to 1,031, including four attempted murders, eight explosives offenses, 60 assaults, and 94 arsons. Samuel Osborne's article that appeared in the UK Independent newspaper (November 22, 2016) stated that German authorities recorded vandalism crimes, such as the spraying of swastikas and neo-Nazi slogans on refugee accommodation. Germany's Federal Criminal Police reported that intermittent attacks on refugees and their homes had remained high since 2016.

\section{H. Radio as Wartime Hate Speech Machine}

Putting the German situation in context, we may say the upsurge of nationalism and nation-state building projects allowed the media to monitor, comment, and produce more stories on hate speech than ever. Media coverage of hate speech also fueled nationalistic sentiments, and it helped create strongmen throughout the First- and Second World Wars eras. Political leaders used posters, advertising, comic books and cartoons, pamphlets, books, movies, animation, magazines, and newspapers in spreading war propaganda and hate speech against their enemies because it had a wider reach. Frequent Modulation (FM) radio networks played a significant role.

The growing radio listening audience, from family members whose relatives were fighting in the wars and local politicians and businesses, fueled media moguls' desire to develop propaganda-based programming to feed the interests of the evolving radio market. Propaganda messages broadcast on radio, television, or newspapers (the latter best accessible in 1914 through the 1960s) included bias words to promote pro-republican agendas. US President Eleanor Roosevelt used a series of radio chats in the evenings to convince most Americans about America's role and its good performance during the Second World War [21]. For his part, German Chancellor Adolph Hitler used reverse psychology on German radio networks on his people. In his speech broadcast, February 1, 1933, two days after his appointment as chancellor, Hitler took control of the media, which resulted in the Third Reich in Germany and massive catastrophes in the history of humanity [22]. Nazi radio propaganda had strong positive effects on anti-Semitic expressions, proxied by anti-Jewish programs during the Black Death from 13481350. Again, Hitler disseminated hate propaganda and created prejudice and intolerance against the Jews, which ultimately resulted in the deaths of six million Jewish men, women, and children. Historians have recorded that Hitler, on various occasions, told the Volk (German audience) that the rest of the world thought of Germany as inferior, second-class citizens, which sparked their supreme hatred for any nonGerman person. [23].

\section{European Hate Speech Laws, a Farce}

The history of hate speech in the European legal system is a dismal one. During the Nuremberg trials, the Convention on the Prevention and Punishment of the Crime of Genocide adopted by the United Nations General Assembly convicted Julius Streicher, a Nazi party cohort and publisher of the sensationalist newspaper Der Stürmer. They had him executed after judging that the paper had incited genocide. From the outset, the article's objective was to promulgate anti-Semitic propaganda; the first issue had an excerpt that stated, "As long as the Jew is in the German household, we will be Jewish slaves. Therefore, he must go"[24]. John Gunther describes Streicher as "the worst of the antiSemites," undoubtedly because of the irresponsible and embarrassing manner he depicted Jews in his widely circulated newspaper [25]. For his part, Snyder explains Stretcher's use of fake anti-Semitic narratives to enrich himself.

Despite his special relationship with Hitler after 1938, Stretcher's position began to unravel. He was accused of keeping Jewish property seized after Kristallnacht in November 1938; he was charged with spreading untrue stories about Göring, such as alleging that he was impotent and that his daughter Edda was conceived by artificial insemination; and he was confronted with excessive personal behavior, including unconcealed adultery, furious verbal attacks on other Gauleiters and striding through the streets of Nuremberg cracking a bullwhip [26].

According to the Holocaust Encyclopedia, the International Military Tribunal (IMT), the best known postwar war crimes body, the publisher of the anti-Semitic German weekly, had committed crimes against humanity by publishing hate ideologies and extremist narratives linked to a surge in the mass murder of Europe's Jewish population. The shamed history of the Nazis and their bullying rhetoric appears to have little impact on Germans as its latter generations, especially the $21^{\text {st }}$ Century youth, have seized 
every opportunity to express their hatred against immigrants.

The unification of West and East Germany on October 3, 1990, ushered in a new type of activism, communication style, vocabulary, and form of expression hitherto benign to both nations. Typically, the idea of merging into one country under one set of laws, sharing national resources can indeed provoke anti-immigrant anti-other sentiments, which can quickly spread among indigenous people and morph into intense hatred for the other people. That hostility can manifest in various ways, including a phobia against migrants from any country.

No wonder the Nazi Party, between 1933 and early 1945, whose political stance was to spread hatred against Jewish people, used taboo words and preached racial purity. Those ideas have reemerged in German political discourse. Over the last several years, news broadcasters, talk show guests, and political scientists on German radio and television networks have commented that 'Volksverrater' ('Traitor of the people') is increasingly heard during anti-refugee protests, especially rallies organized by the anti-Islam Pegida movement. Political figures such as the Frauke Petry, Alternative for Germany (AFD) party leader, publicly used "Völkisch" ("ethnic"), a term Hitler's Nazi Party used to describe those they saw as belonging to the superior German race. While some politicians reportedly argue that the word "Volk" ("people" or "the world") has a positive connotation, other political parties and media pundits consider it essential to Nazi ideology. Osborne states that Petry's word choice represents a policy of exclusion towards those perceived as "non-German"; in other words, refugees and asylum seekers [27].

Germany has become sensitive to hate speech after the disaster caused by the Nazi movement and the holocaust mastermind Adolph Hitler. Still, the country is facing a complicated situation with censorship of hate speech. After the passage of a law authorizing social media platforms to take down posts considered "manifestly illegal," civil libertarians and Human Rights Watch groups have warned against the policy's "vague and broad" definitions of prohibited content. Additionally, a report advocated hatred, which should be prohibited in line with Articles 19(3) and 20(2) of the International Covenant on Civil and Political Rights, establishing a high threshold for limitations on free expression. [28].

\section{J. Presidents, Nationalism, and Hate Speech in the Global West-Framing the Ethnic 'Other'}

Nationalistic hate narratives have not only prevailed during wartimes. Liberal media, particularly those in the US, UK, France, and other western countries, set the public agenda for understanding racial violence. This agenda paints a bias image of minority ethnic groups in urban communities. According to Google data, news coverage of nationalism has been a world event since US President JF Kennedy's election in 1960, then during the Barack Obama era, the first Black person, and that of Donald Trump, the businessman. The media has also scrutinized immigration policies, framing racial groups like Hispanics and Blacks in Europe and America as criminals and sub-humans.

Hate crime has caught the attention of Europe's research community so much that some countries are paying attention to the data, while others are considering ways to implement recommendations. A European Union non-profit project called Bricks Against Hate Speech, which advocates equal opportunities for migrants in education and employment, has reported a significant increase in the use of hate speech among most EU countries. And, recent studies also show that manifestations of hate speech are increasing on websites, blogs, and social networks, especially among young people. In October 2016, studies on why hate crimes were carried out in Italy, Germany, Czech Republic, Spain, and Belgium on migrants and minority groups and published in online newspapers.

Another study compared hate messaging in participating countries in Europe and offered ways "to combat the spread of online hate speech against migrants and minorities through media literacy and active involvement of web users and web content producers" [29].

Regrettably, the presidents of Canada, France, and the United States have publicly voiced their support for ethnic nationalism, unapologetically speaking on their countries' news networks and during annual UN national Assembly meetings in New York against globalization and immigration and supporting nativism and protectionism. They have argued that corporations use the International Monetary Fund (IMF), the World Bank, and the World Trade Organization to undermine local decision-making institutions and exercise privileges that individuals and small businesses cannot sustain. Ironically, the same leaders support their country's corporate and financial interests. Clearly, influential players are using hate speech to shape the new world order - neoliberalism.

Increased legal and illegal migration to the US from Mexico, the West Indies, Africa, and Asia has caused some Americans to feel like their space is being invaded. Some Americans have capitalized on these concerns by verbally attacking immigrants and religious minorities in the streets. These sentiments, regularly covered by www.voanews.com and other news media, feed deeply disturbed minds, like those of the shooter who, on August 3, 2019, at a Walmart store in El Paso, Texas, shot and killed 23 people and injured 22 others. Indeed, speech-induced brutal behavior unsanctioned by state authorities has been replicated in other states.

\section{$K$. Immigration and hate speech promoter}

Those leaders use fiery rhetoric supposedly to protect their country's corporate and financial interests and give their people a sense of national identity. Their statements could be interpreted as fiery and hateful. Here are some examples:

US President Donald Trump says: "We'll make America great again!" Here, we recall that America influenced the outcomes of the First and Second World wars, weakened communism by negotiating the dismantling of the Berlin wall and fighting a winless war against terrorism in Afghanistan and Iraq. The September 11, 2001, terrorist attack in the US that killed some 3,500 Americans and China's steady rise as a world economic superpower has collectively weakened America's image as the premier global superpower. To 'make America great again" is to do whatever it takes to reclaim that position. 


\section{Discussion}

Legal scholars and human rights experts, particularly those involved with the protection of free expression, struggle to distinguish offensive speech from harmful speech because of the differences in national laws, cultures, and personal beliefs. For example, in African agrarian communities, public displays of nudity are not offensive; instead, it provokes intrigue. A girl in her puberty can walk around with an exposed torso without breast wear. In America, public nudity may cause serious harm if it offends some people [30]. A man or woman may be arrested and charged for nudity in most public spaces. However, speech (e.g., bigotry, rudeness, unpatriotic actions like burning the American flag) is protected, especially on university campuses that receive federal funds because the campuses are "public space" as defined by US law.

Students bring beliefs, values, biases, and assumptions learned while growing up and can express them on campus. The American Civil Liberties Union, created in 1920 to defend and preserve individual rights, fosters the idea that every person in America should be guaranteed liberties based on the US Constitution. American law protects civil liberty issues like voting rights, reproductive rights, human rights, free speech, gender rights, religious liberty, racial justice, which further complicates the ability of any organized body to control human expression. It also protects bigoted speech, which is symptomatic of a massive problem in a culturally diverse society like the United States of America.

The prominent American socio-political philosopher Joel Feinberg offers a free version of principles of offensive language far beyond the 'harm' principle [31]. In his work on The Moral Limits of the Criminal Law, Offense to Others, published in 1985 by Oxford University Press, Feinberg focuses on the "offense principle," which states that preventing shock, disgust, or hatred is morally a wrong reason to protect an individual from prosecution.

In fact, word choice and expressions are pertinent to a community's values and perceptions. For example, foul language - cursing - is frequent in informal conversations in America. Still, it is not permissible in Africa or Islamic communities because people meet, greet, and converse in the name of peace. The Quran 2:83 states: "Do not worship except Allah, and to parents do good and to relatives, orphans, and the needy. Speak to people good [words] and establish prayer." Hence, a true Muslim does not use curse words.

Drifting away from African and Islamic communities, we realize that European philosophers and historians have attempted to bring discord between racial groups by advancing the notion of "Caucasians" as the superior race and others as inferior races. The original meaning of "Caucasian" was "Caucasus," "Mountains" [32]. Later, German anatomist and early anthropologist Johann Friedrich Blumenbach in 1795 described it as "one of white," now used intentionally with "white" to represent people of European descent in America.

American historian Bruce Baum offers ample evidence that the concept of a "Caucasian race" is, in fact, remarkably arbitrary. In his book, The Rise and Fall of the Caucasian Race: A Political History of Racial Identity, published by New York University Press in 2006 and republished elsewhere, the historian traces the concept of race and the changing status of "white" people, revealing that the delineation of the term is a socially influenced conception of a European-centered Caucasian race. Baum credits Christoph Meiners (1747-1810), of the University of Göttingen philosopher and historian, as the creator of "Caucasian," as having a racially binding meaning in his Grundriss der Geschichte der Menschheit [33].

Similarly, modern Eurocentric and Afrocentric thinkers have deconstructed "Caucasian," providing sociolinguistic meanings to suit their worldviews. The dictionary meaning of Caucasus or Caucasia refers to the Black and Caspian Seas region, including southwest Russia, Georgia, Azerbaijan, and Armenia. That forms part of the traditional boundary between Europe and Asia. However, modern populations from all or parts of Europe, Western Asia, Central Asia, South Asia, North Africa, and the Horn of Africa. Distinguished European scholars Beckwith [34] and Freedman [35] also point out that the term is used to describe ancient and modern populations from all or parts of Europe, Western Asia, Central Asia, South Asia, North Africa, and the Horn of Africa. Interestingly, we do not find any reference to people in the Horn of Africa as Caucasians in political and other social science research circles, furthering the notion that there is a bias against African people.

Overall, regulations are not effective for various reasonsin the US, the First Amendment grants rights to expression to everyone, making it difficult for law enforcement forces to be influential. In Africa and Asia, especially India, massive corruption exists at all levels, preventing those countries from implementing harmful speech policies. Laws in African countries generally cover behaviors that denigrate or intimidate a person or group based on gender or religion, but authorities do not protect the victims against homophobia. Based on press stories, lesbian, gay, bisexual, and transgender persons who publicly demonstrate their gender preference are consistently attacked verbally and physically in the streets, bars, nightclubs, and other public places. Homosexuality is outlawed in thirty-four African countries except for South Africa and Cape Verde, while Benin and the Central African Republic have specific laws that apply differently to heterosexual and gay individuals. The International Lesbian, Gay, Bisexual, Trans, and Intersex Association published a survey in 2016 in which $51 \%$ of people surveyed felt that being gay, lesbian, bisexual, transgender, or intersex should be a crime, while $41 \%$ said they would feel comfortable if their neighbor were gay or lesbian. The results suggest that the rate of gender-based crimes related to hate speech might grow in most countries, and governments do not take meaningful steps to address the pandemic.

\section{How Football negotiates hate speech}

Sports, especially the Olympic games, rugby, and football, have global appeal-they are watched on television by billions of fans. World and regional football governing bodies have been instrumental in bringing awareness about harmful speech. No wonder world governing bodies use such sporting live events to disseminate messages. FIFA, CONCACAF, EURO, and other regional bodies publish signs on televised football pitches. Before each game, their team captains read statements to fans decrying racism and hate speech because 
the media has consistently broadcast incidents of xenophobic slurs against black players in the press since FIFA, the world soccer (football) governing body, announced a zero-tolerance policy on such verbal attacks.

Since June 2020, Premier League football players in the United Kingdom have taken the knee in solidarity with the Black Lives Matter movement --to highlight racial injustice. During EPL matches, fans who make racial remarks against black players are arrested, fined, or banned from attending future events. Also, during the 2014 FIFA World Cup Tournament held in Brazil, FIFA and Brazilian authorities initiated an anti-racism campaign using the hashtag \#SayNoToRacism. FIFA created a Task Force Against Racism and Discrimination to address diversity and antidiscrimination in football, but strangely it no longer exists. So FIFA's bid to develop concrete solutions to fight discrimination in football, strengthen FIFA's noble campaign, and eliminate racism and hate speech in football is a farce. As of 2021, during the English Premier League and other professional football matches across Europe, fans continue to insult Black players with minor penalties from the football respective governing bodies.

While top European football leagues show a lukewarm attitude, elsewhere, authorities appear more concerned about the dangers of allowing hate speech. In a Pew Research Center publication, Angelina Theodorou acknowledged efforts by the Brazilian government to curb hate speech, stressing that racist or religiously intolerant speech or actions are prohibited by law carrying penalties that include imprisonment [36]. Another Pew Research center study published in 2014 shows that 45\% (89) countries worldwide have hate speech laws. Laws against hate speech are most common in Europe, where $84 \%$ of countries (38 of 45 ) have such laws or policies as of 2012 [36]. In 2008, the European Union passed a framework decision to combat hate speech and other expressions of racism and xenophobia - although member states have yet to enforce the decision consistently.

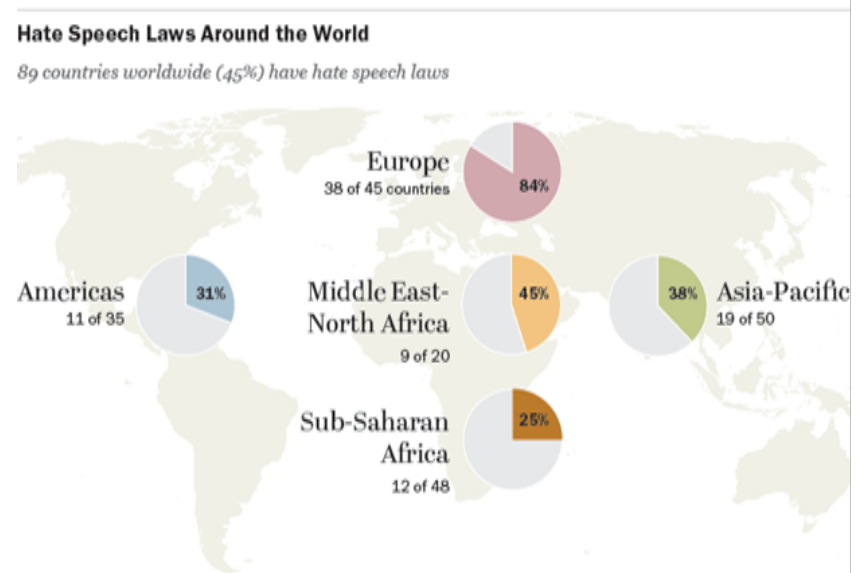

PEW RESEARCH CENTER

Fig 1. Countries with Hate Speech Laws.

Generally speaking, hate speech has caused severe damage to human relationships for centuries. People, especially those in power (e.g., White Supremacists; Nationalists), have put others in a vulnerable situation. Communities and nations with poor, blacks, immigrants, women, LGBTQs, and older people looking for employment, among others, suffer economic setbacks and experience social unrest from racist groups. Whether it happens consciously or unconsciously, people become victims or users of a form of hate speech at one point in time. Both parties suffer from the communication of hate language - the user looking for reprieve or overcome an inherent fear - the receiver suffering psychologically from the impact of derogation.

There are also short and long-term consequences for the language abuser and receiver alike because word choice (and repeated words) affect future behavioral patterns. In short, there would be no winner if we used hate Speech to dominate others because we enslave our psyche in the process.

\section{CONCLuSions}

Based on those discussions, I posit that most hate speech laws in Europe are vague, and authorities have been lackadaisical in implementing them. Although some government-sponsored intelligence agencies like the FBI, DGS (France's foreign intelligence agency), and SIS (Britain's Secret Intelligence Service) work closely with local and international partners to neutralize terrorist cells and operatives, help dismantle extremist networks worldwide, and to cut off financing and other forms of support provided to foreign terrorist organizations, most governments have not taken drastic steps despite the high cost of hate speech proliferation that includes the murder of innocent persons, homophobia, sophisticated racist practices, intense distrust among ethnic groups in a country and the rise of domestic and international terrorism.

Further, (1) hate speech does not target one race; it is common among other races; (2) the ethnic group with the largest population that controls the economy is also a victim of bigotry. (3) People with alternative lifestyles, such as homosexuals, lesbians, and transsexuals, are victims of hate speech, especially in traditional societies and less democratic nations. (4) Ignorance and limited exposure to another culture are fertile grounds for the manifestation of hate speech; (5) hate speech users use fear as a weapon to subjugate others; (6) hate speech is promoted by informal groups that perceive themselves as being in control of others.

Only forty-five percent $(45 \%)$ of UN member countries have hate speech laws with no stringent mechanisms by member states of the world governing body to reprimand violators. International law is not enforced either because the UN has limited technical resources. These most powerful UN Security Councils restrict: China, France, Russia, the United Kingdom, and the United States to oversee international human rights laws on their territory.

Some countries are not committed to implementing international human rights laws, while others have different perceptions of 'free speech and 'human rights.' For example, African countries and most Africans in Europe have clear-cut opinions on gender and gender roles. To them, homosexuality is taboo, so policies that undermine this principle could only exacerbate verbal vitriol against those engaged in such a lifestyle. Thus, parliaments, judiciaries, and human rights advocates within each country face an uphill task in identifying violations and obtaining an urgent response from their respective governments or the United Nations Human 


\section{Rights Council.}

Individuals, businesses, groups, and societies continue to be transformed by hate speech, with the privileged majority group taking advantage of the vagueness of speech laws and the absence of speech policing to advance its agenda and maintain the status quo.

Next, hate speech shared online, in public places, social media platforms, established media, and other socioeconomic structures show that such a communication pattern holds a valuable spot in our consciousness. It is a crucial factor in staging the outcomes of our behaviors.

Last, hate-mongers use their funds and right to free expression to destroy human life, deplete natural resources and weaken economies.

\section{STUDY LimitATIONS}

My analysis of hate speech and Caucasian Nationalism in Western Democracies addressed the Caucasian community in some Western countries; it did not pay much attention to other essential variables such as immigrants from Africa, America, the Middle East, Asia, Central, and South America, or Eastern Europe.

\section{WAYS To TAME THE INVISIBLE GHOST}

Worldviews and sentiments of non-EU citizens, 447.3 million people living in Europe as of January 2021 per Eurostat Statistics (March 2021), need to be assessed to determine the impact of Caucasian nationalism on their wellbeing. More studies should assess the impact of immigration laws and acquisition of citizenship status through asylum by non-EU people on hate speech and the rise of Caucasian nationalism in the European Union.

\section{A. How Media Firms Should Control Hate Speech}

It is difficult for established media to curb hate speech because people can publicly express their thoughts and feelings in Western societies. However, working with humanitarian and human rights groups, media platforms can curb hate speech, mainly because it is costly. Here are some general actions I recommend.

To control their massive influence over the airwaves and online, marketing agencies should stop using Facebook as an advertising platform to disseminate hate speech.

Further, as I have stated before, social media CEOs should collaborate with their respective national governments to monitor prejudicial messages and remove content that threatens to disrupt the lives of vulnerable people in the country and destabilize the political systems of emerging nations [37].

If media agencies put a higher premium on companies that buy ads on programs broadcasting hateful content, they will likely redirect their ad spending to other programs. This would, in turn, reduce the number of news and entertainment programs being produced.

\section{B. How Government Should Control Hate Speech}

i. Governments can levy more taxes on the media institutions that program news and entertainment content.

ii. Stricter laws should be set up and implemented for all public gatherings where hate speech is delivered. The laws should include bottle-neck rules for getting permits to display hate-related free speech.

iii.Legal scholars employed by the State should review and compare cases involving the cost of individual freedoms of expression versus the potential overall damages to the State.

\section{REFERENCES}

[1] M. Lepoutre, "Hate Speech in Public Discourse: A Pessimistic Defense of Counter Speech," Social Theory and Practice 43(4): 851-883, 2017.

[2] A. Gutierrez, UN Strategy and Plan of Action on Hate Speech., June 18, 2019. https://www.un.org/en/genocideprevention/documents/UN.

[3] R. Anderson, Imagined Communities: Reflections on the Origin and Spread of Nationalism. London: Verso, 1991.

[4] M. Finkel, "Theories of Nationalism: A Brief Comparison of Realist and Constructivist Ideas of the Nation." Inquiries Journal 8(10), 2016.

[5] T. Winichakul, "Nationalism and the Radical Intelligentsia in Thailand," Third World Quarterly 29(3): 575-591. 2008.

[6] E. Ngwainmbi, Hate speech and the re-emergence of Caucasian Nationalism in the United States (Chapter 4). London, United Kingdom. 2022.

[7] B. Azarian, Understanding the Racist Brain. Psychology Today. September 24, 2018

[8] D. Amodio and P. Devine, "Stereotyping and Evaluation in Implicit Race Bias: Evidence for Independent Constructs and Unique Effects on Behavior," Journal of Personality and Social Psychology 91(4): 652$661,2016$.

[9] A. Hudson and C. McInnis, "Derogating humor as a DE-legitimization Strategy in Intergroup Contexts," Translational Issues in Psychological Science American 2(1): 63-74: 2016.

[10] https://publichealth.nyu.edu.

[11] UNAIDS. Ending violence and discrimination against lesbian, gay, bisexual, transgender, and intersex people (Press Release) 2015. https://www.unaids.org/en/resources/presscentre/pressreleaseandstate mentarchive/2015/september/20150929_LGBTI.

[12] P. Rivera, Who Are the Proud Boys and Why Are They Banned from Social Media Platforms? Fox40 Sacramento. May 8, 2019.

[13] K. Shanmugam, K. Racial harmony: Five critical steps to keep the peace. The Straits Times. 15 October 2019. https://www.straitstimes.com/opinion/racial-harmony-five-criticalsteps-to-keep-the-peace.

[14] WhatsApp posting shared June 22, 2020. (Personal records)

[15] I. Hussmann, "The Impact of Electronic Media Violence: Scientific Theory and Research," Journal of Adolescent Health 41(1): 6-13, 2007.

[16] M. K. Asante, Identifying Racist Language: Linguistic Acts and Signs, 2003. http://www.asante.net/articles/article.php/?id=38.

[17] https://www.psychologytoday.com/us/blog/mind-in-themachine/201809/understanding-the-racist-brain

[18] https://research.calvin.edu/german-propaganda-archive/rpt27c.htm

[19] https://rantt.com/hitler.

[20] Extract from the Speech by Hitler, January 30, 1939, https://www.yadvashem.org/docs/extract-from-hitler-speech.html.

[21] H. N. Baynes and Micklem, N. "The Speeches of Adolf Hitler," International Affairs Review Supplement 19(9): 485-486, 1942.

[22] A. Rhodes, Propaganda: The art of persuasion: World War II, Chelsea House Publishers, New York, 1976.

[23] M. Adena, R. Enikolopov, M. Petrova, V. Santarosa and E. Zhuravskaya, "Radio and the Rise of the Nazis in Prewar Germany," The Quarterly Journal of Economics, 130(4): 1885-1939, 2015.

[24] https://www.britannica.com/event/Holocaust.

[25] L. R. Bytwerk, Julius Streicher: Nazi Editor of the Notorious AntiSemitic Newspaper "Der Stürmer. New York: Cooper Square Press. 2001.

[26] J. Gunther, Inside Europe. New York: Harper \& Collins, 1940.

[27] L. Snyder, Hitler's Elite: Biographical Sketches of Nazis Who Shaped the Third Reich. New York: Hippocrene Books. 1989.

[28] S. Osborne, Nazi language is becoming increasingly common in Germany's refugee crisis discussion. The Independent (United Kingdom), 2016.

[29] https://www.article19.org/wp-content/uploads/2018/07/GermanyResponding-to- $\%$ E2\%80\%98hate-speech $\%$ E2\%80\%99-v3-WEB.pdf.

[30] https://www.bricks-project.eu.

[31] D. van Mill, "Freedom of Speech," The Stanford Encyclopedia of Philosophy. In Edward N. Zalta (ed.), URL= https://plato.stanford.edu/archives/sum2018/entries/freedom-speech Summer, 2018. 
[32] J. Feinberg, Harm to Others: The Moral Limits of the Criminal Law, Oxford: Oxford University Press. 1984.

[33] J. B. Freedman, "For debate... Caucasian," British Medical Journal. Routledge. 288(6418): 696-98, 1984.

[34] B. Baum, The rise and fall of the Caucasian race: a political history of racial identity. New York: New York University Press. 2006.

[35] C. Beckwith, Empires of the Silk Road: A History of Central Eurasia from the Bronze Age to the Present. Princeton and Oxford: Princeton University Press, 2009.

[36] T. E. Angelina, As FIFA attempts to curb racism at the World Cup, a look at hate speech laws worldwide. June 2014 https://www.pewresearch.org/fact-tank/2014/06/20.

[37] E. K. Ngwainmbi, "Public Prejudicial Discourse as a Global SocioEthnic Phenomenon: Using Digital Media to Limit Detrimental Language Flows," Communication, Society and Media 4(4): 1-23, 2021.

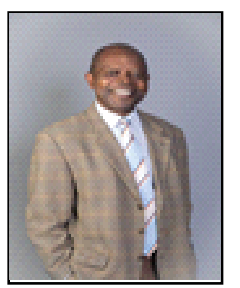

Emmanuel K. Ngwainmbi received a $\mathrm{PhD}$ degree in Human Communication Studies from Howard University, Washington, D.C, USA, in 1991. He specializes in political communication and cyber media. Teaching in the Department of Communication Studies at the University of North Carolina, Charlotte, and a former Senior Editor at Wells Fargo Bank, Prof. Ngwainmbi has taught on various university campuses in the US, Africa, Europe, and Asia for many years. He has received awards from the Chinese Academy for Social Sciences, the Family Christian Association of America, among others and recognized by a Nobel Laureate Archbishop Desmond Tutu, Pulitzer Prize winner Gwendolyn Brooks, for his contribution to the social sciences. Academic credits include Departmental Teacher of the Year and Distinguished Professorial Award. He is listed in Who is Who Among America's Teachers $(\mathcal{C}$, the Communication and Development professionals roster for the UNESCO, UNFPA, UNDP, and other professional rosters. Emmanuel has been a guest on West Africa Democracy Radio and cable television programs across the US, Europe, and Africa, where he has spoken about preserving local cultures in the wake of globalization. After a provocative article on intellectual disparities appeared in Black Issues in Higher Education, he was invited by NPR and some non-profit organizations to discuss African and African American relations.

He has published 20 books and numerous articles in specialized peerreviewed journals, magazines, and e-publications, and some of his works are translated into Mandarin, French, Spanish, Afrikaans, and German. Roman \& Littlefield, the Washington Review, Lynne Reiner, Routledge, Sage, Greenwood Press, university presses, and Palgrave Macmillan are some of his publishers. He is the Volume Editor of Media in the Global Context; Citizenship, Democracies, and Media Engagement among Emerging Economies. Books in press include Dismantling Cultural Borders through Social Media and Digital Communications, and Communicating Pandemics Globally: Focus on Covid-19. He is co-author of Fulton Sheen as a Contemporary Humanist (Lexington Books) and Communicating health and pandemics in Africa: Theory, Practice, \& Guidelines (Cambridge Scholars Publishing Ltd.), forthcoming. 